\title{
Speaking in medias res: Modernism versus Modernity in Sherwood Anderson's Winesburg, Ohio
}

\section{Yonca Denizarslanı ${ }^{1}$ iD}

1 Assist. Prof. Dr., Ege University, Faculty of Letters, Department of American Culture And Literature, İzmir, TURKEY, E-mail: yonca.denizarslani@ege.edu.tr

\begin{abstract}
Since the times of Homeric epics, speaking in medias res has been the most suitable form of storytelling, leaving the threshold of narrative ajar in the present, upholding a historical sense. This ancient historical sense of time, inherent in oral traditions revived in early twentieth century literary Modernism as T. S. Eliot stated in his 1919 essay, "Tradition and The Individual Talent:" "... And it is at the same time what makes a writer most acutely conscious of his place in time, of his own contemporaneity." Be it a messianic revival or primitivism, calling for a coherent context for all, the Modernists were in urge for new narrative techniques overcoming the devastating traumas of the World Wars, representing the shared experiences worldwide. In this respect, early twentieth-century Modernism provided a literary niche for a new generation of storytellers engaged in the momentous grasp of time coalescing with an epiphany. Thus, regarding the present global crises of humanity against which we need to retreat to our local worlds, a review on literary Modernism would suggest a solution as it had once achieved as an internationalist current by gathering the minds and shared experiences in recovering from the overwhelming forces of modernity. This article aims to review literary Modernism and its correspondence with ancient forms of storytelling and sense of time in Sherwood Anderson's Winesburg, Ohio stories regarding the shared thematic motifs transcending the cultural and national boundaries in representing the overwhelming traumas of early twentieth century modernity.
\end{abstract}

Keywords: literary modernism, modernity, ancient storytelling, modern American short story, epiphany 


\section{INTRODUCTION}

Italo Calvino's grandiloquent recalling for classical studies was the most recent vindication of the persistence and prevalence of the classical works, even in today's world literatures:

The classics are books which exercise a particular influence, both when they imprint themselves on our imagination as unforgettable, and when they hide in the layers of memory disguised as the individual's or the collective unconscious....

The classics are those books which come to us bearing the aura of previous interpretations and trailing behind them the traces they have left in the culture or cultures (or just in the languages and customs) through which they have passed. (2000: 11-12)

Towards the fin de siècle of the twentieth century, his essay, Why Read the Classics? (1991) was momentous with the ambivalences and anxieties raised by the World Wars and the new world orders, toppling down the established traditions, conventions, and histories all of which were meant to form the whole sum of world cultures. Hence, in lineage with his early twentieth-century Modernist forerunners, Calvino advocated the flag of internationalism in an age when the wheels of forthcoming globalism of post-modernity was not yet recognized as a threat to national and local cultural identities. In this respect, Calvino's recall for classical studies is urgently grandiloquent for the disillusioned individuals of the twenty-first century post-modernity as it had never been before. In our time, representation, authenticity, and autonomy have been the most problematic issues raised within a new transnational turn. How far can we, the people of diverse cultures, approach each other? To what extend are we bond by the essentials of humanity while clinging to our national and local identities? The legends, folktales, epics and classical genres of both oral and written world literatures and the works of early twentieth-century Modernist literature, which had an aesthetic and ideological lineage to this ancient heritage of collective experience, would provide an answer. Untethered by the biased perspectives and the fault lines of religious motifs and nation-state urgencies, which dated back to fifth century B.C. classical learning along with early JudeoChristian cultures, these ancient genres of oral literature may sustain a platform for the meeting of minds across cultural boundaries either occidental or oriental.

This article aims to focus on the narrative techniques of the ancient storytelling and the Modernist short story, representing a cyclic sense of time and collective experience, which eventually would abode in finding out the concurrent elements recurring in Sherwood Anderson's Winesburg, Ohio (1919)

\section{MODERNISM VERSUS MODERNITY: CONCURRENCE OF A TIMELESS VISION FROM ANCIENT TO MODERN STORYTELLING}

ToPeter Childs, "Modernism has therefore almost universally been considered a literature of not just change but crisis" (2000). In this respect, he differentiates between the terms of 'modernity' and 'modernism:'

In relation to Modernism, modernity is considered to describe a way of living and of experiencing life which has arisen with the changes wrought by industrialization, urbanization, and secularization; its characteristics are disintegration and reformation, fragmentation and rapid change, ephemerality, and insecurity. It involves certain new understandings of time and space: speed, mobility, communication, travel, dynamism, chaos, and cultural revolution. (2000:14)

Regarding this ideological divergence between the terms of 'modernity' and 'modernism,' early twentieth century arts, literature and schools of thought challenged the devastating wheels of modernity observed at all aspects of social and cultural life in the West. Thus, Modernism called for a variety of perspectives aimed at representing the nonrepresentative nature of prevalent conventions, and outer conflicts captivating the artistic and literary creation. Among the various traits in crisis, the break with progressive sense of time, which was inherited from the antecedent century of Hegelian thought, brought about unconventional narrative techniques. The discontent created with the disillusionment of the World Wars, the lost hopes for the foregoing sense of progress and the regressive forces of modernity detached the artistic creativity from the conventional forms of representation. Relevant with this ideological break, the distinction between artistic and literary genres blurred as the new techniques in painting came to correspond new techniques in literature, most prominently exemplified by the reflection of the works of Cézanne, Matisse, and Picasso on Gertrude Stein's Three Lives (1905). In accord with the revolutionary techniques of Modern art, non-linear and fragmented story lines of the lives of three ethnic lower-class women in American South were controversial in giving voice to the oppressed and marginalized subjects, whom Stein found worthy of portraying. The sense of fragmented timeline and characterization offered these artists and authors a comprehensive perspective of an outer reality, representative of an ever-changing momentum of modernity. Urbanization, mechanization of labor, alienation and anonymous lives of the crowds distracted the modern individual in search of meaning. Being surrendered by the unfamiliar outside, the constant inner quest of the characters came to reflect both the authenticity and individuality. Disillusioned by the destructive forces of progress, the Modernists gathered the 
remnants of the past with themomentous grasp of the present through the concurrence of remembrance and epiphany in characterization. Such repetitive and overlapping motifs were concomitant elements in most of American Modernist writing, engaged in recalling for a universalizing collective experience and offering a cyclic sense of time, which they believed would heal the worldwide sense of loss. Stein was among the leading Modernists with a heightened sense of loss as she reflected in her Everybody's Autobiography (1937): "When I was young the most awful moment of my life was when I really realized that the stars are worlds and when I really realized that there were civilizations that had completely disappeared from this earth. And now it happens again. Then I was frightened badly frightened, now well now being frightened is something less frightening than it was" (1993: 12). T. S. Eliot's panoramic illustration of post-war scene in his poem "The Love Song of J. Alfred Prufrock" (1915) is another striking depiction of the sense of loss equivalent of regression:

Let us go then, you and I,

When the evening is spread out against the sky

Like a patient etherized upon a table;

Let us go, through certain half-deserted streets,

The muttering retreats

Of restless nights in one-night cheap hotels

And sawdust restaurants with oyster-shells:

Streets that follow like a tedious argument

Of insidious intent

To lead you to an overwhelming question ...

Oh, do not ask, "What is it?"

Let us go and make our visit. (1934:11)

The speaking persona calls out for a stroll among the ruined scenes of the city "When the evening is spread out against the sky / Like a patient etherized upon a table." Personified with the wounded, the imagery of evening is correlated to an apocalyptic sense of time, which is also identical in his poem "The Wasteland." In his article, "Fear in a Handful of Dust: Analogies of Destruction and Redemption Between Isaiah and T.S. Eliot's The Waste Land," Eunice Soriano Baliong explores the poet's persistent use of allusions to various texts inherited from traditions, myths, and religions:

The Wasteland, written three years after World War II is a profound statement of the devastation of the world and the sunken moral consciousness of the people brought about by the years of industrial revolution and war. The persona speaks as if a prophet that sees all and foresees the coming destruction.
Similarly, the book of Isaiah was written during a time of catastrophic decline when the Northern Kingdom of Israel had a long succession of ungodly kings ... It is the prophet Isaiah, like the poet-prophet Teresias (the persona) in The Waste Land, who stands as the voice of prophecy of the present destruction and the hope to come. (2016)

Hence, this peculiar sense of loss and sense of time had led these Modernists towards a cyclic and holistic notion of time through which the past counts for the present while the past collective experiences count for the dilemmas of the present experience. They rejected the Hegelian notion of progressive spirit inbred in the uncontrollable dialectical clash of forces inhumane and violent. Likewise, at the threshold of his novel The Sun Also Rises (1926), Ernest Hemingway introduced his hopes for his wounded veteran Jack Barnes' spiritual rebirth with an allusion to Ecclesiastes:

One generation passeth away, and another generation cometh; but the earth abideth forever... The sun also ariseth, and the sun goeth down, and hasteth to the place where he arose... The wind goeth toward the south, and turneth about unto the north; it whirleth about continually, and the wind returneth again according to his circuits. ... All the rivers run into the sea; yet the sea is not full; unto the place from whence the rivers come, thither they return again. (1996)

Concerning this motif of "rebirth," T. S. Eliot's remarks in his 1919 essay, "Tradition and The Individual Talent," distinguished artistic creativity with a heightened historical sense, initially having a solitary stance amid the forces of change and embracing the prevalence of past, namely the tradition. However, Eliot's definition for the "individual talent" as conscious of his or her contemporaneity did not mean a mere denouncement of tradition. Rather, he reformulated the artistic and authorial integrity in relation to the past. Thus, his attitude represented an intellectual resistance to the historicism of his age, turning to a cyclic sense of time, which he believed would heal the devastation brought by the forces of modernity. For him, the individual talent could only be distinguished with its lineage to tradition and to the extent it transcended its boundaries "to make it new" in Ezra Pound's terms. In this respect, the artist's contemporaneity dwelled on a lineage with the past rather than having a prospect in the future, which came to connote ambiguity and chaos at the threshold of a World War: “... And it is at the same time what makes a writer most acutely conscious of his place in time, of his own contemporaneity" (Eliot, 2009). Regarding T. S. Eliot's point of view on tradition, William Butler Yeats's messianic vision and the cyclic sense of time in his 1920 poem "The Second Coming," represent a mourning for the loss of a center and the disillusionment of the modern individual: 
Turning and turning in the widening gyre

The falcon cannot hear the falconer;

Things fall apart; the centre cannot hold;

Mere anarchy is loosed upon the world,

The blood-dimmed tide is loosed, and everywhere

The ceremony of innocence is drowned;

The best lack all conviction, while the worst

Are full of passionate intensity. (Yeats, 1989)

The poet's evocation of a "widening gyre" which represents an eternal sense of time, indeed calls for a holistic sense of time. In remembrance of Max Weber's naming of modernity as "disenchantment", the "falcon" is loose without a "falconer." Neverthless, through the mourning tone of the speaking persona for the loss of both spiritual and physical integrity between human being and God; individual and society, the poet announces the Second Coming of Jesus Christ, which at the end would heal the disoriented world.

As evidenced from such Modernists, be it revolutionary as Gertrude Stein or in search for a prophetic calling as Eliot or Yeats, Modernism versus modernity dichotomy offered a variety of narrative possibilities while gathering diverse mindsets, cultures, and traditions worldwide. Crossing the national boundaries, Modernism put forward a timeless vision through its cyclic sense of time and connectedness of collective experience amid the devastating forces of modernity at the turn of the century. The next section on Giambattista Vico's and Carl G. Jung's perspectives on the cyclic sense of time and collective experience will contribute to the overall approach to Sherwood Anderson's Winesburg, Ohio.

\section{GIAMBATTISTA VICO AND CARL G. JUNG ON THE CYCLIC SENSE OF TIME AND COLLECTIVE NATURE OF CULTURE}

In correspondence to Isaac Newton's the Principia (1687), Giambattista Vico wrote his New Science (1744). While the former revolutionized the natural sciences, the latter theorized the study of ancient societies and cultures. On the analogy of manner in both of works, Anthony Grafton asserts that, "Vico's New Science, the massive decoding of ancient history, mythology, and law ... is commonly recognized as one of the founding works of the modern human sciences, a work in some ways as deep and original as the contemporary work that transformed the natural sciences, the Principia of Isaac Newton" (1999). Likewise, Northrop Frye alludes to Vico in his The Great Code: The Bible and Literature (1982). Regarding his study on the historical context of the Bible, Frye introduces Vico's work:
According to Vico, there are three ages in a cycle of history: a mythical age, or age of gods; a heroic age, or age of an aristocracy; and age of people, after which there comes a ricorso or return that starts the whole process over again. Each age produces its own kind of langage, giving us three types of verbal expression that Vico calls, respectively, the poetic, the heroic or noble, and the vulgar, ... These terms refer primarily to three modes of writing, because Vico believed that men communicated by signs before they could talk. (1982:5)

Frye exemplifies the sequence of these three modes of writing corresponding to Vico's three types of verbal expression as poetic, allegorical and descriptive. Under the evolutionary process of Vico's historical ages, Frye formulates his study on the historical context of the Bible: "Vico's three terms, apart from their identification with writing, are extremely suggestive as providing a starting point for thinking about the place of the Bible in the history of language as langage ..." (1982:5). Thus, Frye's suggestion on Biblical studies regarding historical context affirms the connectedness of Modernism with its age as langage of early twentieth-century modernity. Relatively, the correlation between the ancient storytelling, which is epitomized with the genre of epic, and the narrative elements of modern short story based on the impression of a momentous expression of crisis, appears as a concurrent aesthetic connectedness representative of the peculiar spirit of Modernism in search for a center in a decaying world.

On the cyclic notion of time, Vico's frontispiece from the 1744 edition illustrates his formulation of evolutionary and cyclic process of ancient civilizations. Among a plethora of symbolisms observed in the illustration, the figures of Leo and Virgo are noteworthy illuminating his cyclic notion time and being:

The figure of Leo means that the principles of my New Science begin by contemplating Hercules, who is the archetype of the founder celebrated by every pagan nation of antiquity. And it contemplates him as he performs his greatest labour, the slaying of the Nemean lion. ... Leo further marks the starting point of human chronology. For the Greeks, who are the source for all our knowledge of pagan antiquities, reckoned their Olympiads from the first Olympic games, which Hercules founded he instituted the Nemean games to celebrate his victory in slaying the lion. In this way, the chronology of the Greeks begins with the introduction of agriculture among them....

As for Virgo, the astronomers adopted the poet's description of the goddess as crowned with ears of grain. This means that Greek history began in the Golden Age, which the poets clearly celebrate as the world's first age. Indeed, for many centuries years were reckoned according to the harvests of grain, which was the world's first gold. The Greeks' Golden Age corresponds exactly to the Latin's Age of Saturn, a god whose name comes from satus, sowing. ... And we shall also see that the Near 
Eastern peoples, Egyptians, Greeks, and Latins - while unaware of each other's existence - all share uniform ideas which led them to elevate their gods to planets and their heroes to fixed stars. Thus from Saturn, whom the Greek call Kronos or Chronos (meaning 'time'), we derive further basic principles of chronology, the science of time-reckoning. (1999: 2-3)

Concerning Vico's use of symbolisms in his frontispiece, archetypal associations of the ancient cognizance mark the cyclic order of time, as well as gathering the unifying aspects of civilizations, which Jung called as collective consciousness. Joseph Campbell, too, emphasizes the timeless connectedness of myths and collective experience:

For the symbols of mythology are not manufactured; they cannot be ordered, invented, or permanently suppressed. They are spontaneous productions of the psyche, and each bears within it, undamaged, the germ power of its source. What is the secret of the timeless vision? From what profundity of the mind does it derive? Why is mythology everywhere the same, beneath its varieties of costume? And what does it teach? (2004: 40)

Lastly, Emanuel Paparella's interpretation of Vico's frontispiece exemplifies the connectedness between the ancient forms of storytelling and the Modernist recalling of cyclic notion of time:

Within this image, very familiar to those who know anything about Vico, one soon notices that the universe within time and space has been divided into three observed and perceived phenomena: the divine, the human, and the natural world. Observed by whom? By Providence represented as an all seeing eye, but most importantly by man who needs poetic wisdom (represented by Homer receiving the light of providence as reflected by metaphysics). Without these Man cannot ascend to Truth. That image holds all those elements together. Hence the first important observation of Vico's thought is that it represents a philosophy of recollective universals generating philosophical understanding not from rational categories but from the image. (2007)

The frontispiece of New Science

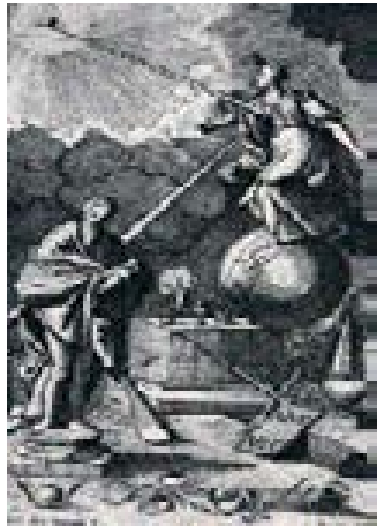

metanexus.net/uniqueness-giambattista-vicos-poetic-philosophy/
Likewise, Carl Gustav Jung's study Archetypes and the Collective Unconscious (1953) illuminates the urge for exploring the undercurrent relation between ancient forms of storytelling and Modern short story. Ahmet Hamit Bozkur's remarks on Jung's archetypal concept of God as an expression of collective unconscious are noteworthy regarding his interpretation of the relationship between the archetypes and their impact on the formation of selfhood, which is closely related to the art of telling and the notion of authorship:

Jung puts forward the idea of God as an archetype of collective unconscious under two separate titles as an archetypal form and archetypal content. He asserted that, deeply rooted in the psyche, the contents of God Image manifest by means of symbols. Thus, regarding the relationship between the archetype of Selfhood and the archetype of God, he suggested that God Image arises in consciousness with the experience of Selfhood that can be achieved by the Process of Individuation, which he also defined as Integration. (2021: vi-vii)

Furthermore, in his chapter, "The Psychology of Rebirth," Jung traces the meaning and the significance of the motif of rebirth by referring to its historical lineage:

So, if we want to find out what rebirth really is, we must turn to history in order to ascertain what "rebirth" has been understood to mean....

Rebirth is an affirmation that must be counted among the primordial affirmations of mankind. These primordial affirmations are based on what I call archetypes. ... it is not surprising that a concurrence of affirmations concerning rebirth can be found among the most widely differing peoples. (1969:122)

Besides referring to the concurrency of rebirth as a product of collective experience of distant cultures, Jung offers a clear understanding of the roots of rebirth motif, as he exemplifies two types of experience: "transcendence of life, and that of one's own transformation" (1969:123). By "transcendence of life" he alludes to the stages of life cycle performed by the ancient rituals, whereas "transcendence of one's own transformation," he underlines the exposure of character as a unified and transcendent expression of selfhood. Jung's diversification of these two types of experience can be observed in the art of telling, namely that of Aristotle's formulation of mythos or plot in his Poetics: "Plot (mythos), says Aristotle, is made through the imitation of representation (mimesis) of action (praxis)" (Thune \& Prigozy, 1973: 29). Referring to the influence of Aristotle's formulation of plot on modern day storytelling, José Angel García Landa highlights the concurrency inherent in both modes of writing:

... it is appropriate that the making of good plots is more difficult than the portrayal of good characters, belonging as it does to 
a higher degree of the teleological development of literature; Aristotle sees the proof of this both in the achievements of early poets and in the difficulty which beginners have to build good plots (2004: 16)

Among a variety of literary traits common for both the ancient Homeric style of storytelling and early twentiethcentury Modernist short story, the sense of past and present and the prophetic attitude of connecting these realms seem most noteworthy. Regarding the well-known argument in handling the literary Modernism as a counter intellectual movement against the discontents of modernity in the West, this recurring collective motif from ancient to modern times associates the works of literature with a representation of a timeless vision as Erich Auerbach exemplified with "Odysseus' Scar." Auerbach named the Homeric disruption of the present by the past as "digression," which provided a release from the momentous crisis at a proportionate level. Thus, the momentous meaning of Odysseus's disguise is attached to his past with his servant Euryclea's recognition of his scar:

The excursus upon the origin of Odysseus' scar is not basically different from the many passages in which a newly introduced character, or even a newly appearing object or implement, though it be in the thick of a battle, is described as to its nature and origin; or in which, upon the appearance of a god, we are told where he last was, what he was doing there, and by what road he reached the scene; indeed, even the Homeric epithets seem to me in the final analysis to be traceable to the same need for an externalization of phenomena in terms perceptible to the senses. Here is the scar, which comes up in the course of the narrative; and Homer's feeling simply will not permit him to see it appear out of the darkness of an unilluminated past; it must be set in full light, and with it a portion of the hero's boyhood ... (Auerbach, 1953: 5-6)

Hence, in illuminating its protagonist through an omniscient perspective, Homer stabilized the action as well as its hero with a meaningful past and present. Then, "as centered on a heroic or quasi-divine figure, on whose actions depends the fate of a tribe, a nation or the human race" (Abrams, 1993:53), the epic form was innovative not only in representing a culture or a civilization at large scale but also in generating the Western archetypal form of an individual hero with a retrospective and prophetic initiative in his deeds. $\mathrm{M}$. H. Abrams broadens the definition of the epic form through its reviving lineage in Western literature from Dante to Edmund Spencer, Herman Melville, Leo Tolstoy and Bertolt Brecht (1993:53). Besides the concurrent and cyclic sense of time in epic form, Homeric calling for the Muses corresponds to the motif of epiphany in Modernist literature. Abrams' entry for the concept of epiphany stems from Judeo-Christian notion as "a particular manifestation of God's presence within the created world," and develops towards the secular adaptation of the term initially appearing in James Joyce's A Portrait of the Artist as a Young Man, as "a sudden sense of radiance and revelation that one may feel while perceiving a commonplace object" (1993:57). In this respect, the modern literary conveyance of epiphany functioned as a source of inspiration by the writer, whereas it represented the inner motivations of a character manifested through a particular action. Thus, the modern sense of epiphany is closely related to perception, which turns out to be a central motif in narrative techniques of Modernist literature as it associates the conscious and subconscious drives of the mind. In lineage with Homeric call for the Muses, then epiphany in Modernist literature appears as a new form of representation, bringing forth a new mode of authorship in the West. What distinguishes early twentieth-century literary Modernism from earlier forms of representation is the poets' and the authors' motivation for experiment. Exemplar of this literary motivation, modern short story transformed the thematic components of the ancient storytelling by challenging the conventional forms and themes of storytelling in Western literature. These ancient motifs of storytelling, which eventually formed the core of epic tradition, have revived in the West in a plethora of forms. Regarding the endurance of this literary heritage, Joseph Campbell comments on myths:

Throughout the inhabited world, in all times and under every circumstance, the myths of man have flourished; and they have been the living inspiration of whatever else may have appeared out of the activities of the human body and mind. It would not be too much to say that myth is the secret opening through which the inexhaustible energies of the cosmos pour into human cultural manifestation. Religions, philosophies, arts, the social forms of primitive and historic man, prime discoveries in science and technology, the very dreams that blister sleep, boil up from the basic, magic ring of myth. The wonder is that the characteristic efficacy to touch and inspire deep creative centers dwells in the smallest nursery fairy tale-as the flavor of the ocean is contained in a droplet or the whole mystery of life within the egg of a flea. (2004:40)

\section{SPEAKING IN MEDIAS RES IN WINESBURG, OHIO STORIES}

In correspondence with the mindset of his age, Sherwood Anderson introduces the thematic and narrative aspects of his short story cycle Winesburg, Ohio (1919) in "The Book of the Grotesques" with a figure of an old writer who is bounded by his thoughts, evading him from writing: "He was like a pregnant woman, only that the thing inside him was not a baby but a youth. No, it wasn't a youth, it was a woman, young, and wearing a coat of mail like a knight" (1992: 22). Thus, Anderson's attribution of the authorial traits to female fertility is not only an epitome of primordial powers 
of recreation prevalently dominant in ancient forms of storytelling, but it is also a godlike and prophetic portrayal of his modern-day author figure who is profoundly distracted by the discontents of his / her age. In her "Women, Sacrality, and Artistic Creativity: Three Winesburg Stories," Nilsen Gokcen affirms this peculiar correlation between sense of time and modern narrative perspective:

In his nostalgia for a much older mythical time when God was an indwelling deity and when words were deeds, Anderson assumes the role of the oral storyteller. His keenness for biblical language results also from the same feeling. This attitude also appears in his primitivism; nearly all of his fiction abounds with litanies for the past when man lived in a pastoral paradise in harmony with Nature and other men. All of Anderson's major characters, whether in the typical Midwestern small town or in the booming city of Chicago, seek desperately to recover the lost meaning of life and that of their own lives in the universe. They instinctively think that at some time past, man lived close to the essence of life and communicated freely with others and God alike. The tension between these displaced characters, whose efforts to renew the mythical time result in frustration, and those who dominate the present and feel no sense of loss constitute the major theme of Winesburg, Ohio. (2002:7)

In her co-study with Nazmi Agll, “Over Her Dead Body: Sherwood Anderson's 'The Man Who Became a Woman' and 'Death in the Woods,"' Gokcen highlights the narrative correspondence between epic form and modern short stories:

The most poetic of all subjects, according to Edgar Allan Poe, is "the death of a beautiful woman." Likewise, in Sherwood Anderson's stories, "The Man Who Became a Woman" and "Death in the Woods," the death of the female body provides the impetus for the young male artist's initiation. Both narrators in these stories perpetuate the patriarchal equation of art and culture with the male and present initiation into manhood and artistic creativity-storytelling in this case-not only as complementary and interchangeable but also as an epic quest. (2005:17)

Regarding the dramatic break emerged with the crisis of modernity; Anderson compiled his twenty-two stories under the title of Winesburg, Ohio, just like how the insulated small Midwestern town lives were gathered in Winesburg. In contrast to self-aggrandized urban individual of the realist novels, Anderson portrayed the broken lives of townspeople, all of whom were stuck in their solitary "grotesqueness" and inner dilemmas in need of expression. Like Gertrude Stein's portrayal of three separate ethnic and lower class women in her Three Lives, Anderson's Winesburg characters represent both the individual and universal realms. Concerning this thematic motif, Ferdinand Tönnies's Gemeinschaft und Gesellschaft (1887) would illuminate both the fin de siècle of nineteenth century and early twentieth century transformations observed in the process of modernity. Against the grain of nineteenth century historicism, most notably represented by Hegel, whodeclared that momentum of history relied on society rather than individual, Gemeinschaft und Gesellschaft offered a wider scope of history, emphasizing the shift from community to society. Joe Harris's preface is noteworthy concerning this close relation between Anderson's thematic choice and sociological analysis of Gemeinschaft und Gesellschaft:

It focuses on the universally endemic clash between small-scale, kinship and neighbourhood-based 'communities' and largescale competitive market 'societies.' This theme is explored in all aspects of life - in political, economic, legal and family structures; in art, religion and culture; in constructions of 'selfhood' and personhood'; and in modes of cognition, language and human understanding. (Harris: 2001)

In agreement with Vico and Jung, Tönnies's conception of history enhances the cyclic and holistic sense of time and place in Winesburg, Ohio stories:

We must situate ourselves completely outside of things we are examining and observe bodies and movements as if with a telescope and microscope. Within the sphere of civilization, these matters are as distinct from each other as the orbits of the heavenly bodies are from the parts and life processes of an elementary organism in the world of nature. On the one hand they are examined on a gigantic and universal scale, on the other in minute and specific detail. From the universal point of view, history itself is nothing more than a part of the destiny of one planet - a chapter in the development of organic life, made possible by the gradual cooling of the Earth. Looked at in detail on the other hand, history is concerned with the environment and conditions of my own daily life - everything to do with human activity that takes place before my ears and eyes. (Tönnies, 2011: 10-11)

In relevance with these formulations, Anderson's disillusioned individuals of a small town represent the collective experience in micro-level, while their disentanglement with the community depict the disparity between tradition and modernity. Their inner struggles, for coming to terms with the ongoing wheels of modernity outside the town limits, inspire the young journalist of the town, George Willard, who appears as a central figure listening and observing the "grotesqueness" surrounding him, captivating his excitement and empathy for experience. In this respect, the stories, gathered as cycles, can be related to journey and becoming of age motifs of the ancient myths and epics. Thus, the portrayal of George Willard's mature figure in one of the lasting stories, called "Sophistication," is not least likely of Odysseus in the opening lines of The Odyssey:

George Willard, the Ohio village boy, was fast growing into 
manhood and new thoughts had been coming into his mind. All that day, amid the jam of people at the Fair, he had gone about feeling lonely. He was about to leave Winesburg to go away to some city where he hoped to get work on a city newspaper, and he felt grown up. The mood that had taken possession of him was a thing known to men and unknown to boys. He felt old and a little tired. Memories awoke in him. To his mind his new sense of maturity set him apart, made of him a half tragicfigure. He wanted someone to understand the feeling that had taken possession of him after his mother's death. (1992: 234)

Young journalist's journey into the stories of townspeople detaches him from his immature sense of time and space and gives him an impetus for writing, which implies a state of mind that leads his departure from the town. Like the journey of Odysseus, who "saw the townlands / And learned the minds of many distant men, /And weathered many bitter nights and days in his deep heart at sea," (Homer, 2007:1), Winesburg stories season George Willard's perspective of reality, consequently estranging him from the comfort zone of his small town. Thus, Anderson's use of setting as a small town reflects the changing conditions of modern life whirling even towards the remotest solitary Midwestern lives. In her "Locating the Short-Story Cycle," Jennifer Joan Smith comments on Anderson's choice of setting and the phenomenon of change in communal life by referring to Sandra Zagarell:

Sandra Zagarell coined the term "narrative community" to describe cycles that privilege a singular setting, emphasize localized language and practices, obfuscate linear/chronological development in favor of progress, render the quotidian in episodic tales, and depict narrators who are "participant / observers. According to Zagarell, "Narrative of community thus represents a coherent response to the social, economic, cultural, and demographic changes caused by industrialization, urbanization, and the spread of capitalism" (2011:2)

As for the common elements of form in ancient mode of plot and modern short story, Anderson's style conjures Aristotle's points on plot. Martin Scofield mentions that, "Form for Anderson had elements of the organic, the lyric and the kinetic, and he saw the writing of a story as an action or a completed movement" (2006: 128). In his The Writer at His Craft, Anderson defines the short story as a representation of sudden momentous revelation of emotions (Stouck, 1990: 28). This state of epiphany is the central motivation of each episodic moment of Winesburg stories. Thus, Abram's definition of epiphany, from Homeric inspiration to JudeoChristian implication for "particular manifestation of God's presence," counts for the expressionist depiction of Winesburg characters. Dwelling on this expressive moment, Anderson invokes a universalizing perspective through the inner conflicts of lonely and alienated townspeople, each of whom are captivated by their delusions of outer reality that turn them into "grotesques." To depict the solipsistic realm of the characters, Anderson uses third person narration, which can be interchangeably considered as the old writer in "The Book of The Grotesque" or the young journalist George Willard, who hears and gathers each one of individual stories. The interwoven structure of the stories is reflected through a kind of prophetic vision of the narrator, depicting the connectedness of their individual moments of epiphany, which also occasionally coalesce with George Willard's encounter with the characters of each story.

As the exemplar of the cyclic narration of collective experience in Winesburg lives, "The Strength of God" tells the story of the Reverend Curtis Hartman. His episodic realm is introduced in medias res of his middle age and comfortable life in Winesburg:

The Reverend Curtis Hartman was pastor of the Presbyterian Church of Winesburg and had been in that position ten years. He was forty years old, and by his nature very silent and reticent. To preach, standing in the pulpit before the people, was always a hardship for him and from Wednesday morning until Saturday evening he thought of nothing but the two sermons that must be preached on Sunday. Early on Sunday morning he went into a little room called a study in the bell tower of the church and prayed. In his prayers there was one note that always predominated. "Give me strength and courage for Thy work, O Lord!" he pleaded, kneeling on the bare floor, and bowing his head in the presence of the task that lay before him. (1992:147)

While the opening lines of the story unfold the dramatic break of the Reverend, the rising action starts with his cry for Divine inspiration: "He wondered if the flame of the spirit really burned in him and dreamed of a day when a strong sweet new current of power would come like a great wind into his voice and his soul and the people would tremble before the spirit of God made manifest in him" (1992: 151). Yet, unexpectedly, he receives the assumed inspiration as he is tempted by the figure of the teacher Kate Swift, seeing her from the bell tower of his church, while studying for his Sunday preaching:

One Sunday morning in the summer as he sat by his desk in the
room with a large Bible opened before him, and the sheets of his
sermon scattered about, the minister was shocked to see, in the
upper room of the house next door, a woman lying in her bed
and smoking a cigarette while she read a book. Curtis Hartman
went on tiptoe to the window and closed it softly. He was horror
stricken at the thought of a woman smoking and trembled also
to think that his eyes, just raised from the pages of the book of
God, had looked upon the bare shoulders and white throat of a
woman. (1992:148-9) Following the crashing of these two remote realms, the 
Reverend is further tempted with a drive to go on watching Kate Swift no matter how hard he struggles with himself. Eventually, by breaking the corner of the window of his bell tower, begins his prolonged inner fight:

In the soul of the minister a struggle awoke. From wanting to reach the ears of Kate Swift, and through his sermons to delve into her soul, he began to want also to look again at the figure lying white and quiet in the bed. On a Sunday morning when he could not sleep because of his thoughts he arose and went to walk in the streets. When he had gone along Main Street almost to the old Richmond place he stopped and picking up a stone rushed off to the room in the bell tower. With the stone he broke out a corner of the window and then locked the door and sat down at the desk before the open Bible to wait. (1992:150)

Thus, with the story of Curtis Hartman, Anderson challenges the confines of institutional religion and the conformism of small-town life. The reverend's inner struggle turns out to be a perilous quest towards his individual integrity with the Divine. For example, upon his next willful attempt to watch Kate Swift, her absence in her bedroom releases him from his desire for her. He rejoices on this blessing moment: "The minister almost wept with joy at his deliverance from the carnal desire to "peep" and went back to his own house praising God" (1992:150). On the other hand, his distraction continues as he starts to question his life, marriage, and career as a reverend. In search of a meaning for leading his life in Winesburg, his sinful drives inspire his reception of Divine power. He realizes the fact that only through a genuine struggle with sinfulness he could achieve Divine wisdom. Leaving aside his pretentious attitudes for life, the Reverend develops towards an understanding that would revive his senses on the meaning of truth. His moment of epiphany appears following his prolonged desire for once more seeing Kate Swift in her bedroom when suddenly his impression of her figure resembles to the painting on the broken edge of the church window. In the eyes of the Reverend, the innocence of the boy figure in the window painting, illustrated in presence of Jesus Christ, is identified with the naked figure of Kate Swift crying, and praying on her bed: "In the lamplight her figure, slim and strong, looked like the figure of the boy in the presence of the Christ on the leaded window" (1992:155). Upon this momentous Divine occurrence, the Reverend suddenly runs outside of his church in need of revelation:

Curtis Hartman never remembered how he got out of the church. With a cry he arose, dragging the heavy desk along the floor. The Bible fell, making a great clatter in the silence. ... Along the street he went and ran in at the door of the Winesburg Eagle. To George Willard, who was tramping up and down in the office undergoing a struggle of his own, he began to talk half incoherently. "The ways of God are beyond human understanding," he cried. "After ten years in this town, God has manifested himself to me in the body of a woman." His voice dropped and he began to whisper. "I did not understand," he said. "What I took to be the trial of my soul was only a preparation for a new and more beautiful fervor of the spirit. God has appeared to me in the person of Kate Swift, the school teacher, kneeling naked on a bed. Do you know Kate Swift? Although she may not be aware of it, she is an instrument of God, bearing the message of truth. (1992:155)

Strangely, the moment that Reverend Hartman enters the office coincides with George Willard's exhaustion following his intimate moment with Kate Swift, which indeed reappears in the next Winesburg story called, "The Teacher." It can be asserted that their concurrent moments of epiphany give the stories a cyclic sense while reflecting on their estrangement and self-reflexive delusions in a small town on the edge of massive transformations of a modern world. Thus, the moment of action rises in medias res of the characters' broken worlds, and finally leading them towards their state of selfhood unfold with a moment of epiphany, through which they are redeemed from their grotesque states. Malcolm Cowley's introduction to Winesburg, Ohio, affirms the revival of a cyclic sense of time and collective experience in Winesburg stories:

All the grotesques hope that George Willard will someday speak what is in their hearts and thus re-establish their connection with mankind. George is too young to understand them at the time, but the book ends with what seems to be the promise that, after leaving Winesburg, he will become the voice of inarticulate men and women in all forgotten towns. (1992:15)

Like the story of the Reverend Curtis Hartman, the remaining Winesburg stories encircle around the unifying collective experience of epiphany, expressive of the cyclic and holistic sense of existence and universal urge for meaning. Regarding the solitary and estranged lives of the townspeople epitomized as the microcosm of modern individual, Peter Childs's reference to Jürgen Habermas's argument on modernity illuminates these characters' psychological states in medias res of their crisis:

For Habermas, modernity is an incomplete project because it continues to attempt its own self-definition through many instances and utterances of identification and projection. But, the counter argument runs, while the dominance of reason and science has led to material benefit, modernity has not fostered individual autonomy or profitable self-knowledge. It has not provided meaning to the world or to spiritual life, religious or otherwise, perhaps reducing humans merely to rational(ising) animals who are increasingly perceived as more complex and consequently more emotionally, psychologically, and technologically dependent. (2000:17) 
Against the current of disparaging forces beyond the private realms of individual lives, the old writer in "The Book of the Grotesque" contemplates on the enduring nature of selfhood in possession of a single truth. In this respect, through the cyclic life span of the narrator identified with the young journalist George Willard and the old writer, the readers receive a holistic sense of collective human experience as the culmination of each of the upgrading experience achieves an existential moment of cognizance. The self-delusional points of view of the estranged modern individual end up in a state of grotesqueness shared by the common experience of a timeless vision:

That in the beginning when the world was young there were a great many thoughts but no such thing as a truth. Man made the truths himself and each truth was a composite of a great many vague thoughts. All about in the world were the truths and they were all beautiful.

The old man had listened hundreds of the truths in his book. I will not try to tell you of all of them. There was the truth of virginity and the truth of passion, the truth of wealth and of poverty, of thrift and of profligacy, of carelessness and abandon.

And then the people came along. Each as he appeared snatched up one of the truths and some who were quite strong snatched up a dozen of them.

It was the truths that made the people grotesques. The old man had quite an elaborate theory concerning the matter. It was his notion that the moment one of the people took one of the truths to himself, called it his truth, and tried to live his life by it, he became a grotesque and the truth he embraced became a falsehood. (1992:23-24)

\section{CONCLUSION}

Under the light of connected motifs of cyclic sense of time and collective experience shared by the ancient modes of storytelling and modern short story, this article exemplified the design in Sherwood Anderson's Winesburg, Ohio stories with reference to the dichotomy of Modernism versus modernity, which appears as Vico's langage of the breakthrough of early twentieth-century Western modernity. Following the World Wars, the sense of loss in a decaying world had toppled down the meaningful moral outlook of traditional communal life, most strikingly depicted with modern American short stories set in small towns. Oppressive and destructive forces of rapid change observed at all aspects of economic, social, and cultural life at the turn of the twentieth century created estrangement, leaving the individual in a solipsistic realm, Anderson called grotesqueness. Thus, the sense of loss, amid which the Modernist mindset challenged the devastating developments such as industrialization and urbanization, brought disillusionment with the outer reality. Relevantly, the destruction occurred out of wars, political and cultural revolutions, the langage of Modernism called for a plethora of perspectives and narrative styles that would offer a recovery from a broken world. In this respect, Modernist literature can be considered as a mode of coming to terms with massive transformations worldwide. Vico's formulation of cyclic sense of history and Jung's interpretation of the motif of "rebirth" through collective consciousness provide a holistic perspective of the relation between ancient modes of storytelling and modern short story, which offers a timeless vision in recovering from the anxieties of change persistent in all ages and today's societies. Hence, the narrative manner of in medias res appears as a unifying mode, re-consolidating the broken bounds between past and present through the epiphany of momentous expression of a vitalizing impulse in Winesburg characters. In accord with this thematic pattern, George Willard, or the old writer of "The Book of The Grotesques," take on a prophetic vision in gathering the episodic stories of Winesburg, Ohio into an organic form, most notably revived with a momentous epiphany.

\section{REFERENCES}

- ABRAMS, M.H., (1993). A Glossary of Literary Terms. Orlando: Harcourt Brace Jovanovich, Publishers

- ANDERSON, S., (1992). Winesburg, Ohio. Penguin Classics.

- AUERBACH, E., (1953). Mimesis. Princeton: Princeton University Press.

- BALIONG, E. S., (2016). "Fear in a Handful of Dust: Analogies of Destruction and Redemption Between Isaiah and T. S. Eliot's The Waste Land." Literary Study, Carayan Journal. 2(1) [online], http://carayan.xu.edu.ph/ fear-in-a-handful-of-dust- analogies-of-destruction-andredemption-between-isaiah-and-t-s-eliots-the-wasteland/ [Accessed on February 12, 2021].

- BOZKIR, A. H., (2021). Analytical Psychology of Carl Gustav Jung in Terms Of Psychology of Religion; And God as an Archetype of Collective Unconscious. MA. Dokuz Eylül University Graduate School of Social Sciences Department of Philosophy and Religion Sciences. (Unpublished Dissertation).

- CALVINO, I., (2000). Why Read The Classics? Vintage.

- CAMPBELL, J., (2004). The Hero With A Thousand Faces. Princeton: Princeton University Press.

- CHILDS, P., (2000). Modernism. London: Routledge.

- COWLEY, M., (1992). Introduction. Winesburg, Ohio. Sherwood Anderson. Penguin Classics.

- ELIOT, T.S, (1934). T.S. Eliot Selected Poems. New York: Harcourt, Brace \& World, Inc.

- ELIOT, T.S., (2009). “Tradition and The Individual 
Talent." [online], Poetry Foundation. https://www. poetryfoundation.org/articles/69400/tradition-and-theindividual-talent [Accessed on March 22, 2021].

- FRYE, N., (1982). The Great Code: The Bible And Literature. San Diego: Harcourt Brace \&Company.

- GOKCEN, N., (2002).“Women, Sacrality, And Artistic Creativity: Three Winesburg Stories. The Sherwood Anderson Review. XXVII (2): 7-19 The Official Publication of The Sherwood Anderson Society.

- GOKÇEN, N. and AGIL, N., (2005). “Over Her Dead Body: Sherwood Anderson's The Man Who Became a Woman and Death in the Woods." Journal of American Studies of Turkey. (21): 17-25.

- HARRIS, J.ed., (2001). Preface. Community And Civil Society. Ferdinand Tönnies. Cambridge: Cambridge University Press.

- HEMINGWAY, E., (1996). The Sun Also Rises. New York: Scribner Classics.

- HOMER, (2007). The Odyssey. London: Vintage Books.

- JUNG, C.G., (1969). The Archetypes and The Collective Unconscious. New York: Princeton University Press.

- LANDA, J. A. G., (2004). "Aristotle's Poetics." SSRN Electronic Journal. [online]. https://www.researchgate.net/ publication/262224737 [Accessed on November 20, 2020].

- PAPARELLA, E., (2007). “The Uniqueness of Giambattista Vico's Poetic Philosophy." Metanexus, [online] $\underline{\text { https:// }}$ metanexus.net/uniqueness-giambattista-vicos-poeticphilosophy / [Accessed on January 11, 2021].

- SCOFIELD, M., (2006). The Cambridge Introduction to the American Short Story. Cambridge: Cambridge University Press.

- SMITH, J. J., (2011). "Locating the Short-Story Cycle." Journal of Short Story in English. 57: 59-79 [online]. http:// journals.openedition.org/jsse/1182. [Accessed on August 14, 2020].

- STEIN, G., (1993). Everybody's Autobiography. Cambridge: Exact Change.

- STOUCK, D., (1990). “Anderson's Expressionist Art.” New Essays on Winesburg, Ohio. John W. Cowley ed. New York: Cambridge University Press.

- THUNE, E. and PRIGOZY, R. eds., (1973). Short Stories: A Critical Anthology. New York: Macmillan Company.

- TÖNNIES, F., (2001). Community And Civil Society. Cambridge: Cambridge University Press.

- VICO, G., (1999). New Science. London: Penguin Books.

- YEATS, W. B., (1989). “The Second Coming." The Collected Poems of W. B. Yeats. [online], Poetry Foundation, https:// www.poetryfoundation.org/poems/43290/the-secondcoming [Accessed on March 22, 2021]. 